International Research Journal of Management, IT \& Social Sciences
Available online at https://sloap.org/journals/index.php/irjmis/
Vol. 6 No. 6, November 2019, pages: 229 238
ISSN: 2395-7492
https://doi.org/10.21744/irjmis.v6n6.799

\title{
Performance Analysis of Pharmaceutical Installation as Basic of Feasibility: A Self-Based Business Unit into General Services Agency
}

I Made Agus Yogeswara Wibawa ${ }^{a}$

I. G. B. Wiksuana ${ }^{\text {b }}$

\section{Article history:}

Received: 18 July 2019

Accepted: 30 September 2019

Published: 13 November 2019

\section{Keywords:}

balanced scorecard; independent business unit; feasibility;

pharmacy installation; public service agency;

\begin{abstract}
This study aims to determine the performance of the Pharmaceutical Installation as a basis for becoming an independent business unit in order to go to the Public Service Agency (BLU) at the Public Hospital in Denpasar, Bali. Performance measurement is a process of evaluating work progress against pre-determined goals and objectives and the results of activities are compared with the intended intentions; and the effectiveness of actions in achieving goals. In this study using a strategic mechanism in the form of a Balanced Score Card (BSC). Data collection techniques such as documentation, questionnaires, and observations. The data analysis technique used is the financial ratios for the financial perspective, the level of satisfaction for the customer perspective, the level of satisfaction for the perspective of growth and learning, while for the perspective of internal business processes using minimum service standards. The results of the 4 perspectives from the Balanced Scorecard show that the performance of the Pharmacy Installation at the Public Hospital in Denpasar is good and deserves to be an independent business unit.
\end{abstract}

2395-7492@ Copyright 2019. The Author. This is an open-access article under the CC BY-SA license (https://creativecommons.org/licenses/by-sa/4.0/) All rights reserved.

\section{Author correspondence:}

I Made Agus Yogeswara Wibawa,

Faculty of Economics and Business, Udayana University, Denpasar, Indonesia.

Email address: yogauchina@gmail.com

\section{Introduction}

Performance measurement is an important thing in the business world. Performance measurement can be used to assess the success of a company. Performance measurement can be used to assess the success of a company. Performance measurement has been used to measure financial performance and the use of standards set by the government so that it is not able to describe the overall performance of the company (Aprilliani et al., 2019; Chang et al., 2017; Gallagher et al., 2014; Febriawati, 2013; Javid et al., 2016, Oseifuah, 2013; Harsetyanto, 2014). The measurement of financial performance only assesses performance for the short term and does not take into account the invisible assets owned by

${ }^{a}$ Udayana University, Denpasar, Indonesia

${ }^{\mathrm{b}}$ Udayana University, Denpasar, Indonesia 
the hospital while the use of government assessment standards only illustrates the utilization of hospital beds and patient handling.

The Balanced Scorecard is a management control tool that translates the mission and strategy of the organization into operational objectives and performance measures with four perspectives namely customer perspective, financial perspective, internal business process perspective, and learning and growth perspective. The financial perspective explains the economic consequences of actions taken in three other perspectives, namely the customer perspective, the internal business perspective, and the learning and growth perspective. The customer perspective defines market segments and customers where business units will compete. The internal business perspective describes the internal processes provided to provide value to customers or owners. Learning and growth perspectives identify the abilities needed by organizations to obtain long-term growth and improvement (Erwinayanti \& Purnomo,2013; Fathoni, 2010; Gurd \& Gao, 2007; Hawa, 2016; Niven, 2008; Pineno, 2002; Rajabi \& Dabiri, 2012; Ridwan et al., 2013). All perspectives are measured using the Balanced Scorecard to assess performance at the Pharmacy Installation of a Public Hospital in Denpasar, Denpasar.

The use of the Balanced Scorecard Approach, as a method of measuring performance at the Public Hospital Pharmacy Installation in Denpasar, will provide an overview of the performance of hospital pharmaceutical installations in the long run which is very useful for management as comprehensive information for organizational success. The Balanced Scorecard as a method of performance measurement, in its implementation, will provide an overview of the success of three other perspectives besides success from a financial perspective that is the customer perspective can show the organization's success in mastering its customers, both in maintaining and attracting new customers. How is the customer's view of the services provided by the company (Kaplan, 2009; Walker \& Dunn, 2006; Riewpaiboon et al., 2007; Robbins \& Judge, 2006). Performance measurement from a customer perspective can determine the level of customer satisfaction if the performance level of customer satisfaction is poor from this perspective will reduce the number of customers in the future even when financial performance looks good. The internal business process perspective of the management is able to know how the quality of services provided by the hospital to its customers, the results of this perspective can be used as a basis for evaluating the quality of service. The last perspective is learning and growth perspective, the hospital can find out how employee productivity and how the development of learning to improve skills towards improving employee quality, so that the results of perspective measurement can be used as a source of information where the management needs to increase training for employees if the results from perspective this is considered not good.

The results of performance measurement with the Balanced Scorecard approach on Public Hospital Pharmacy Installation in Denpasar Denpasar can be used as a comprehensive evaluation of the results of performance measurement from these four perspectives have unsatisfactory results so that the performance of the Pharmacy Installation of Public Hospitals in Denpasar can continue continuously improve its performance in order to achieve the goals and progress of the hospital in the future (Rabbani et al., 2011; Rahmawati, 2016; Sabarguna, 2017; Saokaew et al., 2009).

\section{Literature Review}

Pharmaceutical services are growing, not limited to drug preparation and drug delivery to patients, but need to interact with patients and other health professionals, by carrying out 'Pharmaceutical care' services thoroughly by pharmacists (Directorate General of Pharmaceutical Development and Medical Devices, 2004 ).

The purpose of hospital pharmacy services is to complete pharmacy services so that they can: the right patient, the right dose, the right way of use, the right combination, the right time and the right price (Adisasmito, 2007; Clegg et al., 2015; Denhardt \& Denhardt, 2015). Patients are also expected to receive services deemed necessary by pharmacy so that patients receive effective, efficient, safe, rational, quality and affordable treatment (Directorate General of Pharmaceutical Development and Medical Devices, 2004).

Patient and community demands for the quality of pharmaceutical services requires a change of service from the old paradigm (drug-oriented) to the new paradigm (patient-oriented) with the philosophy of Pharmaceutical Care (Pharmaceutical Services). The practice of pharmaceutical services is an integrated activity with the aim of identifying, preventing and resolving problems related to health (Minister of Health Decree Number 1197/MENKES/SK/X/2004). 


\section{Materials and Methods}

To obtain the data the author needs in writing this study, the authors conducted research at the Public Hospital Pharmacy Installation in Denpasar. The data obtained are from internal hospital Pharmacy Installation. The industry taken in this research plan is the health industry. So the data obtained comes from hospital internal data. Retrieval of data in this research plan is data that reflects the situation at a particular time, namely at three years (2016-2018).

Data collection methods used in this study are non-participant observation methods and questionnaires (Munandar, 2007; Mahmudi, 2003; Mahsun, 2006). Non-Participatory Observation Method in this study was used to obtain data on reports on the realization of the revenue and outcome budget, data on service activities, data on measuring the achievement of targets, patient data, employee data in 2016-2018 at the Public Hospital in Denpasar, Denpasar. The questionnaire method is through submitting a questionnaire to respondents to find out how the level of satisfaction of employees and customers (patients) to the hospital. The data analysis technique in this study uses the measurement of four balanced scorecard perspectives.

\section{Results and Discussions}

The feasibility performance of a Public Hospital Pharmacy Installation in Denpasar was analyzed and measured using the Balanced Scorecard approach. The four aspects of the Balanced Scorecard that have been measured are financial perspective, customer perspective, internal business perspective, and growth and learning perspective.

\subsection{Financial Perspective Performance}

The financial performance of the Pharmacy Installation of a Public Hospital in Denpasar was analyzed from secondary data in the form of financial statements for three years, namely 2016 - 2018. To measure the financial perspective, this was done by using a measuring instrument for value for money or 3E, namely measuring the economy, effectiveness, and performance efficiency. Programs, activities, and organization of Public Hospital Pharmacy Installation in Denpasar.

\section{Economic Ratio}

The economic ratio of Public Hospital Pharmacy Installations in Denpasar is obtained by comparing the realization of installation outcomes with the budget set for three years, namely 2016 - 2018. The outcome data and budget of Public Hospital Pharmacy Installations in Denpasar are obtained from the financial department, namely:

Table 1

Economical ratio of public hospital pharmacy installation in Denpasar 2016-2018

\begin{tabular}{llll}
\hline Year & Realization Outcome & Budget Set & Economic Ratio \\
\hline 2016 & $9,026,513,944.00$ & $9,156,865,050.00$ & $98,58 \%$ \\
2017 & $8,615,254,944.00$ & $8,672,891,050.00$ & $99,34 \%$ \\
2018 & $10,061,570,575.00$ & $12,531,397,712.00$ & $80,29 \%$ \\
\hline
\end{tabular}

Secondary Data, 2019

The results obtained that finance from 2016 to 2018 are classified into economic criteria because it is less than 100\% (Iswari, 2011), which means the realization of outcome from year to year does not exceed the stipulated budget. Seen from 2016 to 2017 there was an increase in the percentage of economic ratios, this increase was due to the large outcome approaching the budget set. This is due to the transfer of hospital policy to the BLU system so that hospitals can loosely make improvements to improve services and increase the amount of medicine, thereby affecting hospital spending. The percentage decrease in economic ratios is seen from 2017 to 2018 by $19.05 \%$, the decrease in this percentage is due to spending that is increasingly organized, so it does not exceed the budget. The initiative that can be carried out by the Pharmacy Installation of a Public Hospital in Denpasar to optimize the economic ratio is to make good use of the budget by making the right drug purchase planning for example by implementing a stock system that

Agus Yogeswara Wibawa, I. M., \& Wiksuana, I. G. B. (2019). Performance analysis of pharmaceutical installation as basic of feasibility: a self-based business unit into general services agency. International Research Journal of Management, IT and Social Sciences, 6(6), 229-238. https://doi.org/10.21744/irjmis.v6n6.799 
must be checked every day, so that the drug does not experience emptiness, choosing products quality drugs by paying attention to drug prices and delivery times, so as to save expenses.

\section{Efficiency Ratio}

To obtain the efficiency ratio of Public Hospital Pharmacy Installation in Denpasar, it is done by comparing the outcome realization to get revenue with the revenue realization set for three years, namely 2016-2018. Data on outcome realization to obtain revenue and realization of the revenue of the Pharmacy Hospital of Public Hospital in Denpasar obtained from the financial department, namely:

Table 2

Efficiency ratio of public hospital pharmacy installations in Denpasar 2016 - 2018

\begin{tabular}{llll}
\hline Year & Realization Outcome & Realization Income & Efficiency Ratio \\
\hline 2016 & $9,026,513,944.00$ & $10,458,012,949.00$ & $86,31 \%$ \\
2017 & $8,615,254,944.00$ & $10,757,245,800.00$ & $80,09 \%$ \\
2018 & $10,061,570,575.00$ & $10,670,832,795.00$ & $94,29 \%$
\end{tabular}

Secondary Data, 2019

The total outcome of the Pharmacy Installation of a Public Hospital in Denpasar to obtain income consists of procurement of hospital medical equipment, provision of hospital health supplies and BPJS and UMUM management services. In table 1 the results of the study show that the efficiency ratio of Public Hospital Pharmacy Installation in Denpasar is efficient. The results obtained that finance in 2016 had a high-efficiency ratio percentage compared to 2017. This was due to the 2016 policy shift and the transition to BLU. In 2017, a one-door system has been implemented in the Pharmacy Installation, resulting in an increase in revenue and better results. In 2018, finance will still be classified as efficient and will increase due to the increase in spending on medicines as the number of patients increases each year. Initiatives that can be carried out are by making appropriate drug purchase planning, focusing more on preparing and managing financial planning, and improving the service system. Improved services are able to retain old patients and attract new patients for treatment, so as to increase hospital revenue. Management of hospital information systems to the maximum can also be done so that hospitals can make efficiency in terms of energy and time (Siregar Charles \& Lia, 2003; Suci, 2015; Suciati et al., 2006; Sugiyono, 2008; Sulistyaningrum, 2017).

\section{Effectiveness Ratio}

The effectiveness ratio of Public Hospital Pharmacy Installations in Denpasar is obtained by comparing revenue realization with revenue targets set for three years, namely 2016 - 2019. Data on revenue realization and revenue targets of Public Hospital Pharmacy Installations in Denpasar can be seen from the following table.

Table 3

Effectiveness ratios of public hospital pharmacy installations in Denpasar 2016 - 2018

\begin{tabular}{llll}
\hline Year & Income Target & Income Realization & Effectiveness Ratio \\
\hline 2016 & $10,552,349,601.00$ & $10,458,012,949.00$ & $99,11 \%$ \\
2017 & $13,583,394,368.00$ & $10,757,245,800.00$ & $79,19 \%$ \\
2018 & $14,605,427,824.00$ & $10,670,832,795.00$ & $73,06 \%$ \\
\hline
\end{tabular}

Secondary Data, 2019

In table 3 it can be seen that revenue realization continues to decline. In 2016 the effectiveness ratio was $99.11 \%$, then in 2017 , the effectiveness ratio was $79.19 \%$, in 2018 the effectiveness ratio decreased by $73.06 \%$. Judging from the budget determination and realization for the determination of this effectiveness indicator, the effectiveness ratio for the Pharmacy Installation of Public Hospitals in Denpasar in 2016 and 2017 and 2018 is generally ineffective. Changes in policy also have an impact on the effectiveness ratio in 2017 and 2018, because in 2017 and 2018 there are changes in regulations on state finances and the State Health Insurance. Initiatives that can be carried out by the Pharmacy Installation of a Public Hospital in Denpasar to optimize the effectiveness ratio from a measuring perspective are 
evaluating the procurement of medicines in the Pharmacy Installation and making the hospital formulary so that all prescriptions are served and income increases.

\subsection{Customer Perspective Performance}

Performance from the customer perspective of the Pharmacy Installation of a Public Hospital in Denpasar was analyzed from primary data using questionnaire aids. The number of questionnaires distributed to customers was 200 and only 140 were returned and all of them fulfilled the requirements for processing, while the total statements in the questionnaire were 8 (eight) statements. The dissemination process is carried out by distributing questionnaires to patients who are taking drugs at the Public Hospital Pharmacy Installation in Denpasar. Measuring the customer's perspective by measuring using a Likert scale. $65.45 \%$ of respondents agreed with the statement submitted through the questionnaire and it can be said that the level of patient satisfaction with the services provided by the hospital pharmacy is high. The main purpose of a hospital pharmacy installation is to provide services to patients who need treatment. The hospital as an institution of health services for the community must be able to improve quality and affordable services by the community in order to realize the highest degree of health (KMRI. NO. 1087 / MENKES / SK / VII / 2010).

\subsection{Internal Business Perspective Performance}

Performance measurement from an internal business perspective at the Pharmacy Installation of a Public Hospital in Denpasar uses 3 (three) service indicators, namely the Dispensing Time indicator, the Drug Availability indicator, and the Patient Network indicator.

\section{Dispensing Time}

The dispensing time indicator of the Pharmacy Installation of a Public Hospital in Denpasar is obtained from direct observation of the dispensing process. The time is calculated from the time the patient submits the prescription until the medicine is ready to be submitted to the patient. The samples used were two hundred recipes randomly taken during rush hour (10:00 to 14:00) at the Public Hospital Pharmacy Installation in Denpasar. Standard dispensing time according to WHO (1993), is 30 minutes for non-concoction recipes and 60 minutes for prescription concoctions. The dispensing time measurement is not carried out at the inpatient installation because the nurses submit the prescription and take the medicine. Dispensing time in this study is divided into non-concoction and concoction recipes. The results showed that the fastest dispensing time for non-concoction recipes was 3 minutes/sheet recipe and the longest time was 39 minutes/sheet recipe with an average of 13 minutes/sheet recipe. Meanwhile, the fastest dispensing time for recipe concoctions is 6 minutes/recipe sheet, the longest time is 79 minutes/recipe sheet with an average of 21 minutes/recipe sheet. Based on these results dispensing time at the Pharmacy Installation of a Public Hospital in Denpasar has met the established standards, which are 30 minutes for non-concoction recipes and 60 minutes for prescription concoctions.

Dispensing time is a critical factor in pharmaceutical services because Hospital Pharmacy Installation is a barrier and the last saturation point before a drug is received and used by a patient. Patients demand dispensing time in pharmaceutical services as short as possible, but the faster the drug service the greater the potential for error. This condition requires the Hospital Pharmacy Installation to seek a quality service system. Based on observations and interviews with Pharmacy Officials at the Public Hospital in Denpasar, the length of time a drug is available is influenced by several factors. One of them is receptivity at the same time as different recipes. So that there is a buildup of recipes that result in a long dispensing time.

The page when the supply of drugs can affect patient satisfaction with the services provided by the Public Hospital Pharmacy Installation in Denpasar. The higher the number of customer complaints, shows that the service at the Hospital Pharmacy Installation is not good. Efforts that have been made by the Pharmacy Installation so that the length of prescription service in the Hospital Pharmacy Installation can be accelerated is being pursued, among others, by proposing the addition of competent human resources in accordance with the needs and continuing to work in collaboration between the Hospital Pharmacy Installation with other health workers (functional medical staff (SMF) and nurses), the use of a SIM to speed up services in the Pharmacy Installation so that the dispensing process becomes shorter.

Agus Yogeswara Wibawa, I. M., \& Wiksuana, I. G. B. (2019). Performance analysis of pharmaceutical installation as basic of feasibility: a self-based business unit into general services agency. International Research Journal of Management, IT and Social Sciences, 6(6), 229-238. https://doi.org/10.21744/irjmis.v6n6.799 


\subsection{Availability of Medicines in Hospital Pharmacy Installations}

The level of availability of drugs is the ability of pharmaceutical installations to provide drugs according to prescriptions or patient requests for prescription services. Drug vacancies are strongly associated with drug procurement management and control in IFRS which will affect the service process (Satibi, 2016). The availability of drugs in this study was measured by comparing a large number of drugs submitted with drugs prescribed at the Pharmacy Installation of a Public Hospital in Denpasar. Based on sample calculations, the number of samples used was 200 sheets of recipes taken randomly in the morning and afternoon. The results showed that the average availability of drugs was $98 \%$. This result is good enough because it is close to $100 \%$. To increase the availability of drugs requires careful planning of drug needs. Factors that cause the availability of drugs have not reached $100 \%$ at the Pharmacy Installation of a Public Hospital in Denpasar are the small inventory of certain drugs such as drugs that are rarely prescribed and slow-moving drugs, different lead times for each Pharmaceutical Wholesaler (PBF). PBF also sometimes experiences drug vacancies due to the late arrival of goods (drugs) from the pharmaceutical industry. In addition, there are some prescription medicines that are not available at the Public Hospital Pharmacy Installation in Denpasar. The results of the availability of drugs obtained in this study are higher than the results of research conducted by Indayani \& Sunartini (2003), in the amount of $89.48 \%$.

\section{Patient Networking}

Measurement of the patient's network is done by looking at the number of patients who did not redeem the prescription at the Hospital Pharmacy Installation. The research subjects were patients who came to the Pharmacy Installation of a Public Hospital in Denpasar, assuming one patient received a prescription so that the number of samples used was the same as the number of samples used in measuring drug availability and dispensing time, which was 50 patient samples. General Patients are randomly selected at the Pharmacy Installation of the Public Hospital in Denpasar per day.

The measurement results show that the average level of networking of General Patients is $99 \%$. This means that the Public Hospital Pharmacy Installation in Denpasar has lost 1\% of customers for general patients. The loss of the customer can be interpreted as a loss of customer or revenue. Public Hospital in Denpasar has a target of all prescriptions (100\% prescription) that must enter the Public Hospital Pharmacy Installation in Denpasar. The loss of customers can be affected because there is patient dissatisfaction regarding the waiting room with limited seating and unsatisfactory facilities, as well as service time, in this case, dispensing time that is too long and the unavailability of drugs in the Pharmacy Installation of a Public Hospital in Denpasar. In addition to internal matters, there are also external matters. The Pharmacy Installation of a Public Hospital in Denpasar lost customers. One of them is still a doctor who writes a prescription to the patient and directs it to a particular pharmacy because the doctor knows that the prescribed drug is not available at the Pharmacy Installation of a Public Hospital in Denpasar. The loss of customers affects the financial performance of the Public Hospital Pharmacy Installation in Denpasar so that it will affect revenue.

This can be overcome by changing the prescription service system, for example by using electronic prescriptions at the Polyclinic, adding facilities at the Public Hospital Pharmacy Installation in Denpasar and providing drug delivery services to the patient's home so that patients do not have to wait for drugs at the Public Hospital Pharmacy Installation in Denpasar. The level of patient networking in this study was higher than the research conducted by Erwinayanti \& Purnomo (2013), with a patient networking rate of $80.97 \%$. Efforts that have been made at the Public Hospital Pharmacy Installation in Denpasar to improve patient networking are by providing drug delivery services to patients so that patients do not wait long at the Pharmacy Installation of a Public Hospital in Denpasar. In addition, another effort is to use electronic prescriptions where doctors directly type the medication in the system so that patients after being examined no longer carry a prescription, because the prescription is definitely entered into the Pharmacy Installation of a Public Hospital in Denpasar.

\section{Growth and Learning Perspective Performance}

Performance measurement on the perspective of growth and learning is to use indicators of employee satisfaction at the Public Hospital Pharmacy Installation in Denpasar. This indicator is found in the questionnaire distributed to employees of the Pharmacy Installation at the Public Hospital in Denpasar. Employee satisfaction was measured using a questionnaire distributed to employees of the Pharmacy Installation at the Public Hospital in Denpasar, as a sample of 21 employees both military, civil servants and contract workers. Factors that are characteristic of respondents are the type of workforce, gender, age, level of education, and length of work. 
$72.73 \%$ of respondents agreed with the statement submitted through the questionnaire and it can be said that the level of employee satisfaction with the hospital was high. Where the satisfaction of employees of the Public Hospital Pharmacy Installation in Denpasar is measured based on satisfaction with salaries, promotions, superiors, coworkers and the work itself. If seen in general, the level of employee satisfaction at the Pharmacy Installation of a Public Hospital in Denpasar is in a good category at $72.73 \%$.

\subsection{Total Performance of Pharmacy Installation of Public Hospitals in Denpasar}

The results of each perspective can be known, namely financial perspective, customer perspective, internal business process perspective, and learning and growth perspective. Each perspective has different results from the four perspectives that get the highest score interpretation interpretation is the perspective of internal business processes and the perspective of learning and growth where in this perspective, the ability of employees can be seen from the variable dispensing time, availability of drugs, drug networking, and motivation so that the Public Hospital Pharmacy Installation in Denpasar must continue to improve the capabilities of employees, so that employees can work quickly and serve patients without any mistakes that make patients feel uncomfortable, with the training provided by Home Pharmacy Installation Sick Public in Denpasar so that it can add to better knowledge, and to motivate the employees so as to increase work enthusiasm.

The lowest value of the four perspectives is the customer perspective, wherein the customer perspective there are heterogeneous types of customers who visit the Pharmacy Installation of a Public Hospital in Denpasar. As a result, there are differences in perceptions in each customer, but the customer's perspective is still in the good category.

The average score of the performance of a Public Hospital Pharmacy Installation in Denpasar is 405. Thus, it can be interpreted that by using a balanced scorecard the Public Hospital Pharmacy Installation in Denpasar is located in the "Good" area. Thus the Pharmacy Installation of a Public Hospital in Denpasar was measured by the balanced scorecard in the good category. It can be assumed that the Pharmacy Installation of a Public Hospital in Denpasar is worthy of being an independent business unit.

\section{Conclusion}

The feasibility of a Public Hospital Pharmacy Installation in Denpasar viewed from a financial perspective for the period of 2016-2018 was measured using Value for Money analysis which was measured using 3 ratios namely economic ratio, efficiency ratio, and effectiveness ratio. From this financial perspective, in general, the Public Hospital Pharmacy Installation in Denpasar can be seen from the economic ratio value categorized as economical, the efficiency ratio value is categorized as efficient, and the value of the effectiveness ratio is categorized ineffective.

The feasibility of a Public Hospital Pharmacy Installation in Denpasar is seen from the customer's perspective through a questionnaire addressed to patients of a Public Hospital Pharmacy Installation in Denpasar and the results of the number of patient data. From the number of respondents, as much as $65.45 \%$ agree with the indicators of the statements submitted in the questionnaire and it can be said that the level of patient satisfaction with hospital performance is high.

The feasibility of a Public Hospital Pharmacy Installation in Denpasar is seen from the perspective of an internal business process seen from 3 indicators namely dispensing time, availability of drugs at the Hospital Pharmacy Installation and patient networking. For dispensing time indicators at the Pharmacy Installation of the Public Hospital in Denpasar it has been well proven the average service time for finished drugs is 3 minutes and for rack drugs 6 minutes. On the indicator of drug availability at the Pharmacy Installation of the Public Hospital in Denpasar, it is already good because the doctor's prescription has followed the Formulary of the Public Hospital in Denpasar. So that doctors prescribe drugs contained in the Formulary of the Public Hospital in Denpasar. Even if there is a drug not available due to distribution problems from the distributor. And the indicators on patient networking can be said to be good because patients always take drugs at the Public Hospital Pharmacy Installation in Denpasar. Even if there are patients who are not netted because the drug is not available.

The feasibility of a Public Hospital Pharmacy Installation in Denpasar can be seen from the perspective of growth and learning through a questionnaire addressed to employees of a Public Hospital Pharmacy Installation in Denpasar. Of the number of respondents, as much as $72.73 \%$ agree with the indicators of the statements submitted in the questionnaire and it can be said that the level of employee satisfaction with hospital performance is high.

Agus Yogeswara Wibawa, I. M., \& Wiksuana, I. G. B. (2019). Performance analysis of pharmaceutical installation as basic of feasibility: a self-based business unit into general services agency. International Research Journal of Management, IT and Social Sciences, 6(6), 229-238. https://doi.org/10.21744/irjmis.v6n6.799 
The performance results of Pharmacy Installation of Public Hospital in Denpasar through four perspectives namely financial perspective, customer perspective, internal business process perspective, and learning and growth perspective viewed from the performance scale to get a value of 405 then the performance of Public Hospital Pharmacy Installation in Denpasar based on the Balanced Scorecard is categorized as good and deserve to be an independent business unit.

\section{Research Limitations}

The research limitations experienced by the authors include:

a) Financial Perspective: only use 1 variable, Value for Money.

b) Customer Perspective: uneven distribution of questionnaires.

c) Internal Business Perspective: only use 3 variables out of the 5 variables found in improving pharmaceutical services

d) Growth and Learning Perspective: just do the questionnaire

It is expected that the limitations experienced by researchers can be considered for further research.

\section{Conflict of interest statement}

The authors declared that they have no competing interests.

Statement of authorship

The authors have a responsibility for the conception and design of the study. The authors have approved the final article.

\section{Acknowledgments}

The authors would like to thank the editor of IRJMIS for their valuable time, support and advice in completing the current study. 
References

Adisasmito, W. (2007). Sistem manajemen lingkungan rumah sakit. Jakarta: Raja Grafindo Persada.

Aprilliani, W. A., Kartinah, N., \& Hardiati, R. S. W. (2019). Analisis Kinerja Instalasi Farmasi di BLUD Rumah Sakit Kota Banjarbaru dengan Metode Balanced Scorecard Berdasarkan Perspektif Keuangan dan Perspektif Pelayanan Periode 2012-2014. Jurnal Pharmascience, 2(2), 88-102.

Chang, C. H., Chiao, Y. C., \& Tsai, Y. (2017). Identifying competitive strategies to improve the performance of hospitals in a competitive environment. BMC health services research, 17(1), 756. https://dx.doi.org/10.1186/s12913-017-2699-9

Clegg, S. R., Kornberger, M., \& Pitsis, T. (2015). Managing and organizations: An introduction to theory and practice. Sage.

Denhardt, J. V., \& Denhardt, R. B. (2015). The new public service: Serving, not steering. Routledge.

Erwinayanti, G. A. P. S., \& Purnomo, A. (2013). Pengukuran kinerja instalasi farmasi rumah sakit umum daerah panembahan senopati bantul dengan pendekatan balanced scorecard (Doctoral dissertation, [Yogyakarta]: Universitas Gadjah Mada).

Fathoni, F. (2010). Analisis Penilaian Kinerja Rumah Sakit dengan Penerapan Balanced Scorecard (Studi Kasus Rumah? ABC?). Jurnal Sistem Informasi, 2(3), 48-57.

Febriawati, H. (2013). Manajemen Logistik Farmasi Rumah Sakit. Yogyakarta: Gosyen Publishing.

Gallagher, J., Byrne, S., Woods, N., Lynch, D., \& McCarthy, S. (2014). Cost-outcome description of clinical pharmacist interventions in a university teaching hospital. BMC health services research, 14(1), 177. https://doi.org/10.1186/1472-6963-14-177

Gurd, B., \& Gao, T. (2007). Lives in the balance: an analysis of the balanced scorecard (BSC) in healthcare organizations. International Journal of Productivity and Performance Management, 57(1), 6-21. https://doi.org/10.1108/17410400810841209

Harsetyanto, T. O. P. (2014). Formulasi Unit Cost Layanan Kesehatan Puskesmas dalam Rangka Penyusunan Rencana Bisnis dan Anggaran (RBA) Badan Layanan Umum (Studi Kasus pada Puskesmas Padas Kabupaten Ngawi). Jurnal Ilmiah Mahasiswa FEB, 3(1).

Hawa, M. D. (2016). Analisis Kinerja Rumah Sakit Berdasarkan Balanced Scorecard di Rumah Sakit Umum Daerah Tanjung Pura.

Indayani, R., \& Sunartini, S. (2003). Pengaruh pelatihan standar pelayanan medis terhadap pengetahuan dan perilaku dokter dalam pengisian rekam medis di RSU Dr. Zainoel Abidin, Banda Aceh (Doctoral dissertation, [Yogyakarta]: Universitas Gadjah Mada).

Iswari, Y. (2011). Analisis faktor risiko kejadian diare pada anak usia dibawah 2 tahun di RSUD Koja Jakarta. Magister Ilmu Keperawatan Tesis.

Javid, M., Hadian, M., Ghaderi, H., Ghaffari, S., \& Salehi, M. (2016). Application of the activity-based costing method for unit-cost calculation in a hospital. Global journal of health science, 8(1), 165. https://dx.doi.org/10.5539\%2Fgjhs.v8n1p165

Kaplan, R. S. (2009). Conceptual foundations of the balanced scorecard. Handbooks of management accounting research, 3, 1253-1269. https://doi.org/10.1016/S1751-3243(07)03003-9

Mahmudi, M. (2003). New Public Management (NPM): Pendekatan Baru Manajemen Sektor Publik. Jurnal Fakultas Hukum UII, 6(1).

Mahsun, M. (2006). Pengukuran kinerja sektor publik. Yogyakarta: BPFE.

Munandar, M. (2007). Budgeting: Perencanaan Pengkoordinasian dan Pengawasan Kerja. Edisi kedua. BPFEYogyakarta, Yogyakarta.

Niven, P. R. (2008). Balanced scorecard: Step-by-step for government and nonprofit agencies. John Wiley \& Sons.

Oseifuah, E. K. (2013). Activity based costing approach to financial management in the public sector: the South Africa experience. European Scientific Journal, 9(1).

Pineno, C. J. (2002). The balanced scorecard with time-driven activity basedcosting: An incremental approach model to health care cost management. J Health Care Finance, 28(4), 69-80.

Rabbani, F., Lalji, S. N., Abbas, F., Jafri, S. W., Razzak, J. A., Nabi, N., ... \& Tomson, G. (2011). Understanding the context of balanced scorecard implementation: a hospital-based case study in Pakistan. Implementation Science, 6(1), 31. https://doi.org/10.1186/1748-5908-6-31

Rahmawati, S. (2016). The implementation of Indonesian case-based groups (Ina-Cbg) of cesarean section patients in poor family health payment assurance in Undata Hospital of Central Sulawesi, Indonesia. International Journal of Health Management and Tourism, 1(1), 57-68.

Agus Yogeswara Wibawa, I. M., \& Wiksuana, I. G. B. (2019). Performance analysis of pharmaceutical installation as basic of feasibility: a self-based business unit into general services agency. International Research Journal of Management, IT and Social Sciences, 6(6), 229-238. https://doi.org/10.21744/irjmis.v6n6.799 
Rajabi, A., \& Dabiri, A. (2012). Applying activity based costing (ABC) method to calculate cost price in hospital and remedy services. Iranian journal of public health, 41(4), 100.

Ridwan, R., Harun, H., An, Y., \& Fahmid, I. M. (2013). The impact of the balanced scorecard on corporate performance: The case of an Australian public sector enterprise. International Business Research, 6(10), 103. http://dx.doi.org/10.5539/ibr.v6n10p103

Riewpaiboon, A., Malaroje, S., \& Kongsawatt, S. (2007). Effect of costing methods on unit cost of hospital medical services. Tropical Medicine \& International Health, 12(4), 554-563. https://doi.org/10.1111/j.13653156.2007.01815.x

Robbins, S. P., \& Judge, T. A. (2006). Perilaku organisasi. Edisi kesepuluh. Jakarta: PT Indeks Kelompok Gramedia.

Sabarguna, B. S. (2017). Peningkatan mutu untuk layanan primer: berbasis sistem informasi.

Saokaew, S., Maphanta, S., \& Thangsomboon, P. (2009). Impact of pharmacist's interventions on cost of drug therapy in intensive care unit. Pharmacy practice, 7(2), 81.

Satibi, S. (2016). National health coverage system: pharmacists and JKN participant satisfaction in primary health facilities. Indonesian Journal of Pharmacy, 27(4), 231.

Siregar Charles, J. P., \& Lia, A. (2003). Farmasi Rumah Sakit: Teori dan Praktek. Penerbit EGC, Jakarta.

Suci, R. P. (2015). Esensi Manajemen Strategi.

Suciati, S., Adisasmito, W. B., \& Wiku, B. (2006). Analisis perencanaan obat berdasarkan ABC indeks kritis di instalasi farmasi. Gadjah Mada University.

Sugiyono. (2008). Metode penelitian pendidikan:(pendekatan kuantitatif, kualitatif dan $R \& D$ ). Alfabeta.

Sulistyaningrum, I. H. (2017). Analisis Kinerja Instalasi Farmasi RSU Daerah X Dengan Pendekatan Balanced Scorecard Pada Perspektif Proses Bisnis Internal. e-Publikasi Fakultas Farmasi, 66-70.

Walker, K. B., \& Dunn, L. M. (2006). Improving hospital performance and productivity with the balanced scorecard. Academy of Health Care Management Journal, 2. 